\title{
Diazinon Mitigation in Constructed Wetlands: Influence of Vegetation
}

\author{
M. T. Moore • C. M. Cooper • S. Smith Jr. • \\ R. F. Cullum • S. S. Knight \\ M. A. Locke • E. R. Bennett
}

Received: 19 December 2006 / Accepted: 19 April 2007 / Published online: 5 May 2007

(C) Springer Science + Business Media B.V. 2007

\begin{abstract}
In intensively cultivated areas, agriculture is a significant source of pesticides associated with storm runoff. When these pollutants enter aquatic receiving waters, they have potential to damage nearby aquatic ecosystems. Constructed wetlands are a best management practice (BMP) designed to help alleviate this potential problem. A constructed wetland system $(180 \times 30 \mathrm{~m})$ comprised of a sediment retention basin and two treatment cells was used to determine fate and transport of a simulated storm runoff event containing the insecticide diazinon and suspended sediment. Wetland water, sediment, and plant samples were collected spatially and temporally over 55 d. Results indicated that $43 \%$ of the study's measured diazinon mass was associated with plant material, while 23 and $34 \%$ were measured in sediment and water, respectively. Mean diazinon concen-
\end{abstract}

All programs of the US Department of Agriculture (USDA) are offered on a non-discriminatory basis without regard to race, color, national origin, religion, sex, marital status, or handicap. Mention of trade names or commercial products is solely for the purpose of providing specific information and does not imply recommendation or endorsement by the USDA.

M. T. Moore $(\bowtie) \cdot$ C. M. Cooper $\cdot$ S. Smith Jr.

R. F. Cullum - S. S. Knight • M. A. Locke $\cdot$ E. R. Bennett

Water Quality and Ecology Research Unit,

USDA Agricultural Research Service National

Sedimentation Laboratory,

PO Box 1157, Oxford, MS 38655, USA

e-mail: mtmoore@ars.usda.gov trations in water, sediment, and plants for the 55-d study were $18.1 \pm 4.5 \mu \mathrm{g} / \mathrm{l}, 26.0 \pm 8.0 \mu \mathrm{g} / \mathrm{kg}$, and $97.8 \pm$ $10.7 \mu \mathrm{g} / \mathrm{kg}$, respectively. Aqueous concentrations fluctuated in the wetlands between 51-86 $\mu \mathrm{g} / 1$ for the first $4 \mathrm{~h}$ of the experiment; however, by $9 \mathrm{~h}$, aqueous concentrations were approximately $16 \mu \mathrm{g} / \mathrm{l}$. During the $55 \mathrm{~d}$ experiment, $0.3 \mathrm{~m}$ of rainfall contributed to fluctuations in diazinon concentrations. Results of this experiment can be used to model future design specifications for mitigation of diazinon and other pesticides.

Keywords Agricultural runoff - BMP. Pesticides · Phytoremediation $\cdot$ Retention

\section{Introduction}

According to the US Environmental Protection Agency (US EPA 2004a), over 441 million $\mathrm{kg}$ of conventional pesticides (e.g. herbicides, fungicides, insecticides, etc.) were used in the US in 2001. Of that total, 77\% were used in agricultural applications, and $11 \%$ were used for home and garden purposes. Through storm runoff, spray drift, or accidental spills, pesticides have the potential to contaminate surface and ground water resources. Increased scrutiny of the US water quality 303(d) program led to a renewed focus on the Total Maximum Daily Load (TMDL) program, originally enacted as part of the 1972 Clean 
Water Act. Approximately 1,200 water body impairments across the US are attributed to pesticides (US EPA 2004b). While agriculture is often targeted as the primary source of these pesticides, many overlook urban use contributions. Studies from the US Geological Survey (USGS) indicated $99 \%$ of major US urban streams are contaminated by at least one pesticide, while slightly over $70 \%$ are contaminated with five or more pesticides (Gilliom 2001). Insecticides make up approximately $10 \%$ of both the US and world pesticide markets and between 1982-2001, the average annual insecticide expenditure in the US was $\$ 2.4$ billion (US EPA 2004a). When many organochlorine insecticides were banned, their replacement pesticides, organophosphates (OP), increased in usage. However, with the 1996 passage of the Food Quality Protection Act, OP insecticides became the primary target group for US EPA's re-registration process. Although OP insecticide usage is down $45 \%$ since 1980 (from 55 to 33 million $\mathrm{kg}$ in 2001), their share of percent total insecticide applied has actually increased from 58\% (1980) to 70\% (2001) (US EPA 2004a).

Diazinon [O,O-diethyl-O-(2-isopropyl-6-methyl-4pyrimidinyl) phosphorothioate] is a non-systemic OP insecticide with agricultural and veterinary uses. Residential, lawn, and garden uses of diazinon were phased out effective December 31, 2004. Still, diazinon is the third most commonly used OP in the US, and over $390,000 \mathrm{~kg}$ of diazinon active ingredient were used in 2002 (Gianessi and Reigner 2006). In California, diazinon is used for treatment of overwintering insects in almonds (Prunus dulcis) and other stonefruit orchards. From 1993 to 2002, almost five million $\mathrm{kg}$ of diazinon were used in California, with an average annual application of $484,000 \mathrm{~kg}$ (California DPR 2003). While diazinon is an effective insecticide, the timing of California's dormant season applications coincides with the wettest months of the year (December through March), resulting in detection of diazinon in California Central Valley water from dormant orchard storm runoff for over 10 years (de Vlaming et al. 2000). Diazinon is also one of the three most frequently detected insecticides in US surface waters (Larson et al. 1997, 1999; Holmes and de Vlaming 2003).

Many best management practices (BMPs) have been suggested to help alleviate pesticide runoff into downstream aquatic receiving systems. One such edge-of-field BMP is constructed wetlands. Wetlands have long been known for their capacity to improve water quality, and recent studies have indicated their success with mitigating agricultural runoff (Wolverton and Harrison 1973; Higgins et al. 1993; Cole 1998; Rodgers et al. 1999; Moore et al. 2002; Schulz et al. 2003a, b; Schulz 2004). Vegetation is an important component of constructed wetlands. Plants provide stabilization of bed sediments, surface area for microbial attachment and growth, and physical filtration (Brix 1994). The presence of organic matter assoy4ciated with wetland plants also aids in pesticide mitigation by increasing their potential to transfer from the water to plant material. Other studies have focused on benefits of vegetation in decreasing diazinon concentrations in runoff. For example, using inter-row vegetative filter strips, $37 \%$ of applied diazinon remained within the vegetated filter strip that provided $50 \%$ coverage. When coverage of the inter-row filter strip was increased to $100 \%, 88 \%$ of applied diazinon remained in the filter strip (Watanabe and Grismer 2001). Total runoff pesticide loading in areas supporting ground cover crops could be reduced by approximately 50\% (Watanabe and Grismer 2001). This same study recommended that potential diversion of runoff water through wetlands (or other practices aimed at increasing hydraulic residence time) may successfully mitigate effects of pesticides entering downstream aquatic receiving systems. The objective of this research was to evaluate the use of a constructed wetland system for mitigating diazinon runoff from sources such as dormant orchard spray applications, irrigation tailwater runoff, or row crop storm runoff. A constructed wetland in the Mississippi Delta, USA, was used to accomplish the objective.

\section{Materials and Methods}

\subsection{Study Site Description}

Beasley Lake watershed, in Sunflower County, Mississippi, comprises 850 ha of land surrounding a 25 ha oxbow lake (Locke 2004). Adjacent to the southeast corner of Beasley Lake, a $180 \times 30 \mathrm{~m}$ constructed wetland system was established in spring 2003 . The system consisted of an initial sediment retention basin, followed by two individual cells (Weaver et al. 2004). Ten stations at distances from inflow of $1 \mathrm{~m}$ (site 1), 
$10 \mathrm{~m}$ (site 2), $15 \mathrm{~m}$ (site 3), $30 \mathrm{~m}$ (site 4), $60 \mathrm{~m}$ (site 5), $85 \mathrm{~m}$ (site 6), $90 \mathrm{~m}$ (site 7), $120 \mathrm{~m}$ (site 8), $150 \mathrm{~m}$ (site 9), and $170 \mathrm{~m}$ (site 10) were established within the constructed wetland system for collection of water, sediment, and plant samples (Fig. 1).

\subsection{Simulated Storm Runoff Event}

A simulated storm runoff event was conducted on the constructed wetland system in May 2003. Diazinon 4E $\mathrm{E}^{\mathrm{TM}}$ (32 $\mathrm{g}$ active ingredient total), suspended sediment $(403 \mathrm{mg} / \mathrm{l})$, and surface water from Beasley Lake (Table 1) were mixed together in a 7,570 L chamber for $1 \mathrm{~h}$ before being continuously amended into the wetland system through a metal flume at the upper end for $4 \mathrm{~h}$. Amount of diazinon used was based on the recommended application rate in California (2.25 kg active ingredient/ha); wetland contributing acreage (14 ha); and assumed 1\% pesticide runoff (Wauchope 1978). Simulated rainfall contributions to the storm event were based on a $1.3 \mathrm{~cm}$ event, with assumed rainfall runoff of $50 \%$ ( $\sim 917,000 \mathrm{~L})$. A pump $(\sim 3,800 \mathrm{~L} / \mathrm{min})$ transported water from the lake into the wetland system for $4 \mathrm{~h}$ to complete the simulated runoff event.

\subsection{Collection of Water, Sediment, and Plant Samples}

Grab samples of wetland water were collected in 1-L amber glass bottles at $15 \mathrm{~min}$ intervals for the first hour, then again at $1.5 \mathrm{~h}, 2 \mathrm{~h}, 3 \mathrm{~h}, 4 \mathrm{~h}, 9 \mathrm{~h}, 1 \mathrm{~d}$, and $2 \mathrm{~d}$ at individual sampling sites indicated in Fig. 1. When available, water was also collected on days 7 , $13,27,41$, and 55 post-application at sampling sites. However, with no inflow after the $4 \mathrm{~h}$ simulated event, certain wetland sampling stations were dry after 7 days. After collection, samples were stored on ice and immediately returned to the laboratory for extraction
Table 1 Pesticide concentrations $(\mu \mathrm{g} / \mathrm{L})$ in Beasley Lake water (used as source water for storm runoff)

Pre-study (4/30/03) Post-study (5/19/03)

\begin{tabular}{lll}
\hline Trifluralin & 0.000 & 0.000 \\
Atrazine & 0.206 & 0.227 \\
Methyl parathion & 0.015 & 0.015 \\
Alachlor & 0.000 & 0.000 \\
Metolachlor & 0.020 & 0.011 \\
Chlorpyrifos & 0.000 & 0.000 \\
Cyanazine & 0.006 & 0.002 \\
Pendimethalin & 0.000 & 0.000 \\
Fipronil & 0.010 & 0.011 \\
Fipronil sulfone & 0.002 & 0.001 \\
Dieldrin & 0.002 & 0.001 \\
pp'-DDE & 0.004 & 0.002 \\
pp'-DDD & 0.006 & 0.003 \\
pp'-DDT & 0.024 & 0.014 \\
Chlorfenapyr & 0.008 & 0.004 \\
Bifenthrin & 0.015 & 0.006 \\
Lambda- & 0.005 & 0.002 \\
cyhalothrin & &
\end{tabular}

(within $24 \mathrm{~h}$ ). Approximately $10 \mathrm{~g}$ (wet weight) of sediment and plant material were collected at 1, 3, 9, 24 , and $48 \mathrm{~h}$, as well as 7, 13, 27, 41, and $55 \mathrm{~d}$. Sediment samples were limited to the top $3 \mathrm{~cm}$, and only leaves and shoots exposed in the water column (from sediment surface to water surface) were collected as plant samples. Samples were wrapped in foil, stored on ice, and transported to the laboratory. Upon arrival, samples were stored in a freezer $\left(-20^{\circ} \mathrm{C}\right)$ until being dried for analysis.

\subsection{Diazinon Extraction and Analysis}

Pesticide analyses were conducted on unfiltered water, sediment, and plants to determine diazinon
Fig. 1 Sampling stations located within the Beasley Lake constructed wetland system. Sites with a, b, and c were collected along the same transect

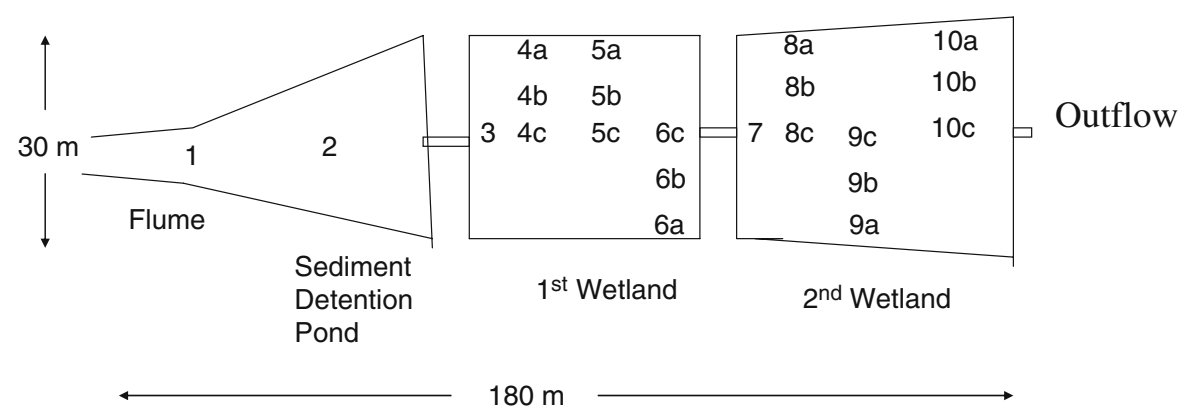


concentrations in the three environmental matrices. Extraction methods used were similar to those detailed by Bennett et al. (2000). Individual water sample volumes were recorded $(500-800 \mathrm{ml})$ prior to addition of $200 \mathrm{ml}$ of ethyl acetate and $100 \mathrm{mg}$ of $\mathrm{KCl}$. Sediment and plant samples were air-dried and ground to pass through a $2 \mathrm{~mm}$ sieve, prior to extraction. Diazinon was analyzed using an Agilent Technologies 6890 gas chromatograph equipped with a $30 \mathrm{~m}$ Agilent Technologies-1 MS column (Santa Clara, CA). An Agilent electron capture detector (model G2397A) was utilized. A multi-level calibration procedure was used with standards (99.4\% purity, USEPA, Research Triangle Park, NC) and updated every ninth sample. Limits of detection (LOD) in water, sediments, and plants were $0.01 \mu \mathrm{g} / \mathrm{l}, 0.1 \mu \mathrm{g} / \mathrm{kg}$, and $0.1 \mu \mathrm{g} / \mathrm{kg}$, respectively. Mean extraction efficiencies based on fortified samples, were $>90 \%$ for water, sediment, and plants.

\subsection{Data Analysis}

Mass balances were performed using a model developed previously by Bennett et al. (2005) and Moore et al. (2006). Briefly, data on water, plant, and sediments collected along transects of the sediment detention pond, vegetated wetland cell no. 1 and vegetated cell no. 2 (Fig. 1) at each sample time point ( $1 \mathrm{~h}, 3 \mathrm{~h}, 9 \mathrm{~h}, 24 \mathrm{~h}, 48 \mathrm{~h}, 7 \mathrm{~d}$ and $13 \mathrm{~d}$ ) were used to calculate mass balances. Because water data was unavailable due to dry conditions at some locations after $13 \mathrm{~d}$, no further mass balances were derived for comparisons of the three environmental matrices (water, plant, and sediment).

Mass balances for each compartment were compared between cells and total pesticide mass in each compartment was compared to determine overall relative partitioning within the entire system. This enabled quantitative evaluation of chemical partitioning and losses that occurred over the study duration. The mass balance at a given time point, using wetland cell no. 1 as an example, was determined as:

$m_{\mathrm{total}(t)}=m_{\mathrm{w}(0-70)}+m_{\mathrm{p}(0-70)}+m_{\mathrm{s}(0-70)}$

where $m_{\mathrm{w}(0-70)}, m_{\mathrm{p}(0-70)}$ and $m_{\mathrm{s}(0-70)}$ reflect the total chemical mass $(\mathrm{g})$ in water, plants (that part exposed in water column) and sediments over the $70 \mathrm{~m}$ wetland length. Integration of chemical masses in water was performed according to the trapezoidal rule:

$m_{\mathrm{w}(0-70)}=\sum_{i=0}^{n-1}\left(\left(v_{\mathrm{w}(i+1)}-v_{\mathrm{w}(i)}\right) \cdot\left(\frac{C_{\mathrm{w}(i+1)}+C_{\mathrm{w}(i)}}{2}\right)\right)$

where the term $\left(V_{\mathrm{w}(i+1)}-V_{\mathrm{w}(i)}\right)$ represents the volume of water (L) bounded by a given transect interval (i.e. 0-13, 13-46, 46-69 m etc.) and is multiplied by the average water concentration $\left(C_{\mathrm{w}}\right)$ measured at the interval boundaries. Water volumes between transects were estimated using the mean water depth $(0.60 \mathrm{~m})$ multiplied by the surface area of the transect interval and by accounting for water displacement by plants (assuming $20 \%$ of water was displaced by plant biomass in each transect). Mass calculations for plants and sediments were similar to Eq. 2 except that concentrations were measured in units of $\mathrm{mg} / \mathrm{kg}$ and the volume terms were replaced by bulk sediment mass $(\mathrm{kg})$ or plant biomass $(\mathrm{kg})$. In the former case, wetland surface area $\left(\mathrm{m}^{2}\right)$ within a given interval was multiplied by a sediment depth of $0.01 \mathrm{~m}$ and converted to sediment mass by assuming a bulk sediment density of $1,773 \mathrm{~kg} / \mathrm{m}^{3}$. Average area plant biomass $\left(6.96 \mathrm{~kg} / \mathrm{m}^{2}\right)$ within a transect interval was multiplied by wetland width and interval distance to arrive at a plant biomass $(\mathrm{kg})$ estimate.

\section{Results}

\subsection{Diazinon Concentrations}

Progression of diazinon transport in the water column was documented after $30 \mathrm{~min}$ post-exposure. Aqueous diazinon concentrations were $132 \mu \mathrm{g} / \mathrm{l}$ (site 1), $133 \mu \mathrm{g} / \mathrm{l}$ (site 4), $104 \mu \mathrm{g} / \mathrm{l}$ (site 5), $35 \mu \mathrm{g} / \mathrm{l}$ (site 6) and below detection at site 7 (Table 2). Four hours following exposure initiation, diazinon had migrated $150 \mathrm{~m}(15 \mu \mathrm{g} / \mathrm{l})$ within the water phase. Outflow $(180 \mathrm{~m})$ aqueous concentrations were $7.5 \mu \mathrm{g} / 1$ at $6 \mathrm{~h}$ and $23 \mu \mathrm{g} / \mathrm{l}$ at $9 \mathrm{~h}$. When comparing concentrations of diazinon in the entire wetland system throughout the $55 \mathrm{~d}$ experiment, the mean concentrations were $18.1 \pm$ $4.50 \mu \mathrm{g} / \mathrm{l}, 26.0 \pm 8.02 \mu \mathrm{g} / \mathrm{kg}$ (dry weight), and 97.8土 $10.7 \mu \mathrm{g} / \mathrm{kg}$ (dry weight) in water, sediment, and plant compartments, respectively. Wetland plants were associated with $69 \%$ of the measured diazinon con- 
Table 2 Mean ( \pm standard error) diazinon concentrations $(\mu \mathrm{g} / \mathrm{L})$ in wetland water

\begin{tabular}{|c|c|c|c|}
\hline \multirow[t]{2}{*}{ Time (days) } & \multicolumn{3}{|l|}{ Sediment } \\
\hline & $\begin{array}{l}\text { Detention pond } \\
\text { (sites 1-2) }\end{array}$ & $\begin{array}{l}\text { Wetland no. } 1 \\
\text { (sites 3-6) }\end{array}$ & $\begin{array}{l}\text { Wetland no. } 2 \\
\text { (sites } 7-10)\end{array}$ \\
\hline 0.01 & $72.8 \pm 63.0$ & $65.34 \pm 66.5$ & ns \\
\hline 0.02 & $108 \pm 20.7$ & $69.0 \pm 60.12$ & ns \\
\hline 0.03 & $128 \pm 27.1$ & $117 \pm 57.0$ & $0.07 \pm 0.12$ \\
\hline 0.04 & $86.4 \pm 70.0$ & $79.2 \pm 51.4$ & $0.04 \pm 0.12$ \\
\hline 0.06 & $102 \pm 16.0$ & $91.3 \pm 57.5$ & $0.07 \pm 0.10$ \\
\hline 0.08 & $106 \pm 19.9$ & $122 \pm 36.8$ & $0.23 \pm 0.46$ \\
\hline 0.13 & $108 \pm 13.2$ & $107 \pm 42.2$ & $20.2 \pm 37.6$ \\
\hline 0.17 & $35.7 \pm 61.6$ & $86.1 \pm 44.8$ & $34.4 \pm 48.8$ \\
\hline 0.25 & $7.50 \pm 3.90$ & $64.9 \pm 37.9$ & $14.9 \pm 21.3$ \\
\hline 0.38 & $14.5 \pm 0.60$ & $29.2 \pm 33.0$ & $10.6 \pm 12.4$ \\
\hline 1 & $16.3 \pm 6.90$ & $34.5 \pm 22.1$ & $17.3 \pm 21.1$ \\
\hline 2 & $0.09 \pm 0.13$ & $0.44 \pm 1.05$ & $0.01 \pm 0.02$ \\
\hline 7 & $0.59 \pm 0.72$ & $1.68 \pm 2.15$ & $0.51 \pm 0.80$ \\
\hline 13 & $0.93 \pm 1.09$ & $3.12 \pm 2.86$ & $2.46 \pm 2.37$ \\
\hline 27 & bd & $0.06 \pm 0$ & $0.32 \pm 0.79$ \\
\hline 41 & bd & $0.61 \pm 1.36$ & $0.14 \pm 0.26$ \\
\hline 55 & $3.26 \pm 5.16$ & $0.67 \pm 1.42$ & $0.20 \pm 0.48$ \\
\hline
\end{tabular}

$n s=$ no sample collected $b d=$ below detection limits $(0.01 \mu \mathrm{g} / \mathrm{L})$ USEPA acute and chronic water quality criteria for diazinon= $0.17 \mu \mathrm{g} / \mathrm{L}$

centrations, while sediment and water were responsible for 18 and $13 \%$, respectively. Within the first $24 \mathrm{~h}$, $15 \%$ of the inflow diazinon concentration was retained in the sediment detention pond. Wetland cell 1 retained $19 \%$ of its inflow concentration, while wetland cell 2 retained $86 \%$ of its inflow concentration within the first $24 \mathrm{~h}$. Diazinon concentrations in sediment and plants were less predictable throughout the $55 \mathrm{~d}$ experiment (Tables 3 and 4). Fluxes in sediment and plant pesticide concentrations may be related to rainfall which occurred during the $55 \mathrm{~d}$. Between the $48 \mathrm{~h}$ and $7 \mathrm{~d}$ samples, $2.34 \mathrm{~cm}$ of rainfall was recorded. An additional $2.64 \mathrm{~cm}$ fell between the 7 and $13 \mathrm{~d}$ samples. For the 2 week period between 13 and $27 \mathrm{~d}$ samples, $3.48 \mathrm{~cm}$ of rainfall was recorded; however, the greatest amounts of rainfall occurred between 27 and $41 \mathrm{~d}$ samples $(11.51 \mathrm{~cm})$ and between 41 and $55 \mathrm{~d}$ samples $(9.32 \mathrm{~cm})$.

\subsection{Diazinon Mass}

The total nominal mass of diazinon (as active ingredient) added to the wetland system was $32 \mathrm{~g}$. In comparison,
Table 3 Mean ( \pm standard error) diazinon concentrations $(\mu \mathrm{g} / \mathrm{kg})$ in wetland sediment

\begin{tabular}{llll}
\hline Time (days) & \multicolumn{3}{l}{ Sediment } \\
\cline { 2 - 4 } & $\begin{array}{l}\text { Detention pond } \\
\text { (sites 1-2) }\end{array}$ & $\begin{array}{l}\text { Wetland no. 1 } \\
\text { (sites 3-6) }\end{array}$ & $\begin{array}{l}\text { Wetland no. 2 } \\
\text { (sites 7-10) }\end{array}$ \\
\hline 0.04 & $89.6 \pm 155$ & $28.1 \pm 52.4$ & $12.5 \pm 18.4$ \\
0.13 & bd & $21.6 \pm 43.3$ & $7.93 \pm 13.7$ \\
0.38 & $8.26 \pm 11.7$ & $216 \pm 479$ & $17.6 \pm 21.5$ \\
1 & $0.64 \pm 0.90$ & $32.3 \pm 63.3$ & $0.10 \pm 0.18$ \\
2 & bd & $8.35 \pm 9.77$ & $14.1 \pm 11.7$ \\
7 & bd & $6.51 \pm 10.3$ & $115 \pm 219$ \\
13 & $22.4 \pm 31.7$ & $2.61 \pm 5.22$ & $2.18 \pm 3.78$ \\
27 & bd & $49.5 \pm 70.0$ & $7.66 \pm 13.3$ \\
41 & bd & $46.7 \pm 71.3$ & $17.7 \pm 30.7$ \\
55 & bd & $25.5 \pm 34.6$ & $28.9 \pm 50.0$ \\
\hline
\end{tabular}

$b d=$ below detection limits $(0.1 \mu \mathrm{g} / \mathrm{kg})$

the total calculated mass of diazinon for the entire wetland system $\left(m_{\text {total }(\text { detention }+ \text { wetland } 1+\text { wetland 2) }}\right)$ at the $3 \mathrm{~h}$ sampling point was calculated to be $104 \mathrm{~g}$ (Table 5). Model assumptions of wetland water volume and sediment and plant biomass can lead to overestimates of actual pesticide mass present in the system. The mass balance model used for this study has been used in similar wetland studies with success (Bennett et al. 2005; Moore et al. 2006). Mass balance calculations for different sampling times within the three cells of the wetland system showed that there were changes in component distribution occurring over the study duration (Table 5). Throughout

Table 4 Mean ( \pm standard error) diazinon concentrations $(\mu \mathrm{g} / \mathrm{kg})$ in wetland plants

\begin{tabular}{lccc}
\hline Time (days) & \multicolumn{3}{l}{ Sediment } \\
\cline { 2 - 4 } & $\begin{array}{l}\text { Detention pond } \\
\text { (sites 1-2) }\end{array}$ & $\begin{array}{l}\text { Wetland no. 1 } \\
\text { (sites 3-6) }\end{array}$ & $\begin{array}{l}\text { Wetland no. 2 } \\
\text { (sites 7-10) }\end{array}$ \\
\hline 0.04 & $90.4 \pm 0$ & $126 \pm 35.0$ & $44.2 \pm 45.4$ \\
0.13 & $101 \pm 0$ & $232 \pm 139$ & $208 \pm 148$ \\
0.38 & $173 \pm 35.9$ & $90.4 \pm 24.0$ & $136 \pm 128$ \\
1 & $139 \pm 137$ & $76.8 \pm 14.9$ & $241 \pm 123$ \\
2 & $120 \pm 74.4$ & $106 \pm 32.1$ & $119 \pm 62.5$ \\
7 & $106 \pm 88.6$ & $35.0 \pm 53.3$ & $157 \pm 85.8$ \\
13 & $4.40 \pm 6.22$ & $28.3 \pm 22.6$ & $147 \pm 35.8$ \\
27 & $\mathrm{bd}$ & $339 \pm 443$ & $37.0 \pm 3.44$ \\
41 & $8.99 \pm 12.7$ & $8.91 \pm 11.4$ & $74.5 \pm 32.0$ \\
55 & $55.7 \pm 78.8$ & $5.60 \pm 9.69$ & $80.6 \pm 0$
\end{tabular}

$b d=$ below detection limits $(0.1 \mu \mathrm{g} / \mathrm{kg})$ 
Table 5 Diazinon mass data for Beasley Lake constructed wetland system

\begin{tabular}{|c|c|c|c|c|c|}
\hline Time & Cell & Water (\%) & Sediment $(\%)$ & Plants (\%) & Mass (g) \\
\hline $1 \mathrm{~h}$ & $\begin{array}{l}\text { Detention pond } \\
\text { Wetland } 1 \\
\text { Wetland } 2\end{array}$ & $\begin{array}{l}95.1 \\
91.8 \\
3.70\end{array}$ & $\begin{array}{l}4.70 \\
4.90 \\
26.5\end{array}$ & $\begin{array}{l}0.200 \\
3.30 \\
69.8 \\
\text { Total Mass }\end{array}$ & $\begin{array}{l}6.11 \mathrm{E}-02 \\
57.2 \\
1.69 \\
59.0\end{array}$ \\
\hline $3 \mathrm{~h}$ & $\begin{array}{l}\text { Detention pond } \\
\text { Wetland } 1 \\
\text { Wetland } 2\end{array}$ & $\begin{array}{l}99.8 \\
92.7 \\
87.5\end{array}$ & $\begin{array}{l}\text { N.C. } \\
\text { N.C. } \\
0.300\end{array}$ & $\begin{array}{l}0.200 \\
7.30 \\
12.2 \\
\text { Total Mass }\end{array}$ & $\begin{array}{l}9.16 \mathrm{E}-02 \\
53.4 \\
50.5 \\
104\end{array}$ \\
\hline $9 \mathrm{~h}$ & $\begin{array}{l}\text { Detention pond } \\
\text { Wetland } 1 \\
\text { Wetland } 2\end{array}$ & $\begin{array}{l}73.5 \\
46.9 \\
63.6\end{array}$ & $\begin{array}{l}8.80 \\
47.7 \\
5.40\end{array}$ & $\begin{array}{l}17.7 \\
5.40 \\
31.0 \\
\text { Total Mass }\end{array}$ & $\begin{array}{l}1.18 \mathrm{E}-02 \\
27.7 \\
15.1 \\
42.8\end{array}$ \\
\hline $24 \mathrm{~h}$ & $\begin{array}{l}\text { Detention pond } \\
\text { Wetland } 1 \\
\text { Wetland } 2\end{array}$ & $\begin{array}{l}81.3 \\
94.8 \\
61.5\end{array}$ & $\begin{array}{l}0.200 \\
0.0238 \\
0.084\end{array}$ & $\begin{array}{l}18.5 \\
5.20 \\
38.5 \\
\text { Total Mass }\end{array}$ & $\begin{array}{l}1.03 \mathrm{E}-02 \\
20.6 \\
18.9 \\
39.5\end{array}$ \\
\hline $48 \mathrm{~h}$ & $\begin{array}{l}\text { Detention pond } \\
\text { Wetland } 1 \\
\text { Wetland } 2\end{array}$ & $\begin{array}{l}4.40 \\
8.50 \\
0.200\end{array}$ & $\begin{array}{l}\text { N.C. } \\
6.80 \\
16.3\end{array}$ & $\begin{array}{l}95.6 \\
84.7 \\
83.5 \\
\text { Total Mass }\end{array}$ & $\begin{array}{l}1.80 \mathrm{E}-03 \\
1.81 \\
4.36 \\
6.17\end{array}$ \\
\hline $7 \mathrm{~d}$ & $\begin{array}{l}\text { Detention pond } \\
\text { Wetland } 1 \\
\text { Wetland } 2\end{array}$ & $\begin{array}{l}32.2 \\
71.7 \\
9.70\end{array}$ & $\begin{array}{l}\text { N.C. } \\
15.1 \\
11.8\end{array}$ & $\begin{array}{l}67.8 \\
13.2 \\
78.5 \\
\text { Total Mass }\end{array}$ & $\begin{array}{l}2.44 \mathrm{E}-03 \\
1.60 \\
6.39 \\
7.99\end{array}$ \\
\hline $13 \mathrm{~d}$ & $\begin{array}{l}\text { Detention pond } \\
\text { Wetland } 1 \\
\text { Wetland } 2\end{array}$ & $\begin{array}{l}41.3 \\
48.3 \\
57.0\end{array}$ & $\begin{array}{l}57.1 \\
18.3 \\
2.70\end{array}$ & $\begin{array}{l}1.60 \\
33.4 \\
40.3 \\
\text { Total Mass }\end{array}$ & $\begin{array}{l}8.34 \mathrm{E}-04 \\
0.864 \\
6.09 \\
6.95\end{array}$ \\
\hline
\end{tabular}

N.C. $=$ not calculated (diazinon not detected) sediment retention basin, sediment played a minor role in the partitioning of diazinon (Table 5).

Only $4 \%$ of the overall diazinon water mass was located in the sediment detention pond, while wetland cell 1 had $37 \%$ of the mass, and $59 \%$ of the aqueous mass was located in wetland cell 2. Sediment pesticide masses followed a similar pattern with $<1 \%$ of the overall diazinon sediment mass located in the sediment retention basin, $46 \%$ in wetland cell 1 , and $54 \%$ in wetland cell 2. Diazinon plant masses were partitioned into $<1 \%$ (sediment retention basin), $21 \%$ (wetland cell 1), and 79\% (wetland cell 2).

Evaluating the entire $55 \mathrm{~d}$ exposure period, $44 \%$ of measured diazinon mass in the sediment retention basin was associated with the water column. Plants accounted for $55 \%$ of diazinon mass, while only $1 \%$ was associated with the sediment. In wetland cell 1 , $34 \%$ of diazinon mass was in the water, while 36 and $30 \%$ were associated with sediments and plants, respectively. Wetland cell no. 2 had $24 \%$ diazinon 
mass associated with water, $33 \%$ associated with sediments, and $43 \%$ associated with plants.

\section{Discussion}

Diazinon's water solubility $\left(68.8 \mathrm{mg} / \mathrm{l}\right.$ at $\left.20^{\circ} \mathrm{C}\right)$ and $K_{\mathrm{oc}}$ values $(180-430)$ indicate the pesticide's tendency to remain in the water (Sharom et al. 1980; Watanabe and Grismer 2001). By remaining in the aqueous phase, diazinon concentrations may be detrimental to fish, invertebrates, and other fauna associated with aquatic receiving ecosystems. According to the USEPA, both acute and chronic freshwater ambient water quality criteria for diazinon are $0.17 \mu \mathrm{g} / \mathrm{l}$ (US EPA 2005). As demonstrated in Table 2, aqueous concentrations in wetlands were occasionally below the established criteria. However, instead of focusing on individual wetland aqueous concentrations, one should examine the final wetland cell (no. 2) aqueous concentrations. For the first $3 \mathrm{~h}$ of the experiment, concentrations were below the criteria. From 3-24 h sampling, concentrations exceeded the criteria, but were back below the criteria after $48 \mathrm{~h}$.

Effects of technical grade diazinon in aquatic microcosms have been reported (Giddings et al. 1996). Zooplankton and macroinvertebrate taxa were affected at time-weighted average diazinon concentrations of $9.2 \mu \mathrm{g} / \mathrm{l}$ and greater. At concentrations of $22 \mu \mathrm{g} / \mathrm{l}$ and higher, total fish biomass was reduced, while survival effects were noted at concentrations of $54 \mu \mathrm{g} / 1$ and above. Other studies have reported effects of diazinon on laboratory-reared organisms. When comparing the relative sensitivity of Ceriodaphnia dubia, Daphnia magna, Hyalella azteca, Chironomus tentans, and Pimephales promelas, it was reported that $C$. dubiawas the most sensitive of those species, with a no-observed effects concentration (NOEC) of $0.6 \mu \mathrm{g} / \mathrm{l}$ and a lowest-observed effects concentration (LOEC) of $0.8 \mu \mathrm{g} / \mathrm{l}$. These results translated into a exposure response slope of $300 \%$ mortality $/ \mu \mathrm{g} / \mathrm{l}$. In contrast, $P$. promelas (fathead minnow) was the least sensitive species with an exposure response slope of $0.005 \%$ mortality $/ \mu \mathrm{g} / \mathrm{l}$ (Burkepile et al. 2000). Daphnia magna followed $C$. dubiain sensitivity in the same study, but its exposure response slope was less pronounced $(26 \%$ mortality/ $/ \mathrm{g} / \mathrm{l})$ than $C$. dubia. Other studies of D. magnareported depression of growth at concentrations above $0.05 \mathrm{ng} / \mathrm{l}$, which were sub-lethal (Sanchez et al. 1998). Recently, the presence of other pesticides in solution with diazinon have been documented to increase diazinon's independent toxicity. In the presence of atrazine concentrations between $40-200 \mu \mathrm{g} / \mathrm{l}$, diazinon toxicity to $C$. tentans increased (Belden and Lydy 2000). When the pyrethroid esfenvalerate was present with diazinon, greater than additive toxicity was observed in $P$. promelas (Denton et al. 2003).

To alleviate potential contamination of aquatic receiving system resources surrounding agricultural areas, various management practices have been suggested for implementation. One such practice, constructed wetlands, has been successful at mitigating concentrations of pesticides leaving the agricultural production landscape (Moore et al. 2000, 2002; Sherrard et al. 2004). Biotic and abiotic factors associated with constructed wetlands work in conjunction to remediate pesticide runoff. Microbial activities in wetlands are less understood than other components, but are nonetheless integral in the remediation process. An earlier study conducted on the current constructed wetland system reported similar general enzymatic activities between sediments from the two main cells (Weaver et al. 2004). No microbial data were collected in the current study.

Another important environmental characteristic in constructed wetland systems is $\mathrm{pH}$. Rapid degradation of diazinon via hydrolysis has been reported under acidic conditions (Bailey et al. 1996). In freshwater aqueous solutions, diazinon degradation has increased 2-4 times during temperature increases from 10 to $21^{\circ} \mathrm{C}$ (Bondarenko et al. 2004). With a mean ambient air temperature of $29^{\circ} \mathrm{C}$ during the current experiment and previously reported wetland water $\mathrm{pH}$ values of 4.85-5.21 (Weaver et al. 2004), diazinon degradation was likely increased in the constructed wetland.

To further understand fate of diazinon in this series of vegetated wetland systems, mass balance calculations were performed to determine diazinon partitioning between water, sediment and plant components. At the $3 \mathrm{~h}$ sample collection, it was evident that the majority of the mass of diazinon was calculated to be in the water (Table 5). This mass was evenly distributed between wetland cells 1 and 2 , indicating that advection was a major process occurring in these wetland systems. By $9 \mathrm{~h}$, the mass in water was still evenly distributed between wetland cells 1 and 2 , but the overall mass throughout the 
system had decreased from 104 to $42.8 \mathrm{~g}$ indicating a reduction of greater than $50 \%$. This major loss was likely due to advection since diazinon was measured at the outflow of wetland cell 2 between the 3 and $9 \mathrm{~h}$ sampling points. Interestingly, at the $24 \mathrm{~h}$ sampling collection, overall mass within the system was similar to what was measured at the $9 \mathrm{~h}$ sampling point indicating the wetland system was retaining the remaining diazinon mass (Table 5). After the $24 \mathrm{~h}$ sampling point, the mass of diazinon in water was reduced by two orders of magnitude, while the plant component remained consistent and the sediment component partitioning was minimal. This trend continued throughout the study. These data show diazinon was being degraded in the wetland system, since diazinon mass was decreasing after the $24 \mathrm{~h}$ sampling period and diazinon was no longer measured in the outflow of the wetland system.

It was expected that aquatic macrophytes would play a more important role in the retention of diazinon in this test system since they were effective in a previous study using the organophosphate insecticide, methyl parathion (Moore et al. 2006). In that study, a $5.5 \times 50 \mathrm{~m}$ vegetated wetland dominated by the aquatic macrophyte, Juncus effusus, was shown to successfully reduce methyl parathion concentrations to $0.1 \%$ of the inflow concentration within a $20 \mathrm{~m}$ reach. Furthermore, methyl parathion was not detected in the outflow. In the current study, overall retention of diazinon by aquatic macrophytes was not as evident. There are several possibilities as to why this difference in plant sorption was evident. Perhaps Polygonum amphibium(dominant macrophyte in wetland cell 2), was simply not as effective in sorbing diazinon as was the case with methyl parathion and $J$. effususin the above study. Alternatively, surface sorption sites may have been saturated with diazinon throughout the study. Evidence for this is indicated by calculated mass data where after the $3 \mathrm{~h}$ sampling period, the diazinon mass in plants remained relatively consistent throughout the study (7.00 $\mathrm{g} \pm 0.861)$ until the $13 \mathrm{~d}$ sampling period. Also, reported $K_{\mathrm{oc}}$ values for methyl parathion are 3-5 times greater than those in diazinon, which may account for increased methyl parathion plant sorption. Further plant-pesticide specific studies are needed to address this concern.

Acknowledgments Authors thank L. Arbuckle, J.L. Bouldin, T. Flemons, F. Gwin, Jr., J.T. Hill, R.L. Lee, R.E. Lizotte, Jr., D.
Shaw, R.W. Steinriede, Jr., T. Sullivan, S. Testa III, and T.D. Welch for field assistance and J. Swint for laboratory analyses. Special thanks to S.S. Knight and P. Rodrigue for wetland design information. Thanks also to D.L. Denton for technical assistance and manuscript review.

\section{References}

Bailey, H. C., DiGiorgio, C., Kroll, K., Miller, J. L., Hinton, D. E., \& Starrett, G. (1996). Development of procedures for identifying pesticide toxicity in ambient waters: Carbofuran, diazinon, chlorpyrifos. Environmental Toxicology and Chemistry, 15, 837-845.

Belden, J. B., \& Lydy, M. J. (2000). Impact of atrazine on organophosphate insecticide toxicity. Environmental Toxicology and Chemistry, 19, 2266-2274.

Bennett, E. R., Moore, M. T., Cooper, C. M., \& Smith, S., Jr. (2000). Method for the simultaneous extraction and analysis of two current use pesticides, atrazine and lambda-cyhalothrin, in sediment and aquatic plants. Bulletin of Environmental Contamination and Toxicology, 64, 825-833.

Bennett, E. R., Moore, M. T., Cooper, C. M., Smith, S., Jr., Shields, F. D., Jr., Drouillard, K., et al. (2005). Vegetated agricultural ditches for the mitigation of pyrethroid associated runoff. Environmental Toxicology and Chemistry, 24, 2121-2127.

Bondarenko, S., Gan, J., Haver, D. L., \& Kabashima, J. N. (2004). Persistence of selected organophosphate and carbamate insecticides in waters from a coastal watershed. Environmental Toxicology and Chemistry, 23, 2649-2654.

Brix, H. (1994). Functions of macrophytes in constructed wetlands. Water Science Technology, 4, 71-78.

Burkepile, D. E., Moore, M. T., \& Holland, M. M. (2000). Susceptibility of five nontarget organisms to aqueous diazinon exposure. Bulletin of Environmental Contamination and Toxicology, 64, 114-121.

California DPR. (2003). Use trends of cholinesterase-inhibiting pesticides http://www.cdpr.ca.gov/docs/pur/pur02rep/ trends02.pdf.

Cole, S. (1998). The emergence of treatment wetlands. Environmental Science and Technology, 32, 218A-223A.

Denton, D. L., Wheelock, C. E., Murray, S. A., Deanovic, L. A., Hammock, B. D., \& Hinton, D. E. (2003). Joint acute toxicity of esfenvalerate and diazinon to larval fathead minnows (Pimephales promelas). Environmental Toxicology and Chemistry, 22, 336-341.

de Vlaming, V., Connor, V., DiGiorgio, C., Bailey, H. C., Deanovic, L. A., \& Hinton, D. E. (2000). Application of whole effluent toxicity test procedures to ambient water quality assessment. Environmental Toxicology and Chemistry, $19,42-62$.

Gianessi, L., \& Reigner, N. (2006). Pesticide use in US crop production: 2002. Insecticides and other pesticides. Washington, DC: CropLife Foundation Report.

Giddings, J. M., Biever, R. C., Annunziato, M. F., \& Hosmer, A. J. (1996). Effects of diazinon on large outdoor pond microcosms. Environmental Toxicology and Chemistry, $15,618-629$. 
Gilliom, R. J. (2001). Pesticides in the hydrologic system What do we know and what's next? Hydrological Processes, 15, 3197-3201.

Higgins, M. J., Rock, C. A., Bouchard, R., \& Wengrezynek, B. (1993). Controllingagricultural runoff by use of constructed wetlands. In G. A. Moshiri (Ed.), Constructed wetlands for water quality improvement (pp. 359-367). Boca Raton, Florida: CRC.

Holmes, R. W., \& de Vlaming, V. (2003). Monitoring of diazinon concentrations and loadings, and identification of geographic origins consequent to stormwater runoff from orchards in the Sacramento River watershed, USA. Environmental Monitoring and Assessment, 87, 57-79.

Larson, S. J., Capel, P. D., \& Majewski, M. S. (1997). Pesticides in surface waters: Distribution, trends, and governing factors. Chelsea, Michigan: Ann Arbor.

Larson, S. J., Gilliom, R. J., \& Capel, P. D. (1999). Pesticides in streams of the United States - Initial results from the National Water-Quality Assessment Program. US Geological Survey Water-Resources Investigations Report 98-4222.

Locke, M. A. (2004). Mississippi Delta Management Systems Evaluation Area: Overview of water quality issues on a watershed scale. In M. T. Nett, M. A. Locke, \& D. A. Pennington (Eds.), Water quality assessments in the Mississippi Delta: Regional solutions, national scope (pp. 1-15). Washington, DC: ACS Symposium Series 877.

Moore, M. T., Bennett, E. R., Cooper, C. M., Smith, S., Jr., Farris, J. L., Drouillard, K., et al. (2006). Influence of vegetation in mitigation of methyl parathion. Environmental Pollution, 142, 288-294.

Moore, M. T., Rodgers, J. H., Jr., Cooper, C. M., \& Smith, S., Jr. (2000). Constructed wetlands for mitigation of atrazineassociated agricultural runoff. Environmental Pollution, 110, 393-399.

Moore, M. T., Schulz, R., Cooper, C. M., Smith, S., Jr., \& Rodgers, J. H., Jr. (2002). Mitigation of chlorpyrifos runoff using constructed wetlands. Chemosphere, 46, 827-835.

Rodgers, J. H., Jr., Dickson, G. W., Dillon, T., Dorn, P. B., Farmer, J. E., Gearheart, R. A., et al. (1999). Workgroup V synopsis: Constructed wetlands as a risk mitigation alternative. In M. A. Lewis, F. L. Mayer, R. L. Powell, M. K. Nelson, S. J. Klaine, M. G. Henry, \& G. W. Dickson (Eds.), Ecotoxicology and risk assessment for Wetlands. Pensacola: SETAC.

Sanchez, M., Sanchez, F. E., \& Andreu-Moliner, E. (1998). Evaluation of a Daphnia magna renewal life-cycle test method with diazinon. Journal of Environmental Science and Health. Part B, 33, 785-797.

Schulz, R. (2004). Field studies on exposure, effects, and risk mitigation of aquatic non-point source insecticide pollution: A review. Journal of Environmental Quality, 33, 419-448.

Schulz, R., Moore, M. T., Bennett, E. R., Farris, J. L., Smith, S., Jr., \& Cooper, C. M. (2003a). Methyl parathion toxicity in vegetated and non-vegetated wetland mesocosms. Environmental Toxicology and Chemistry, 22, 1262-1268.

Schulz, R., Moore, M. T., Bennett, E. R., Milam, C. D., Bouldin, J. L., Farris, J. L., et al. (2003b). Acute toxicity of methyl parathion in wetland mesocosms: Assessing the influence of aquatic plants using laboratory testing with Hyalella azteca. Archives of Environmental Contamination and Toxicology, 45, 331-336.

Sharom, M. S., Miles, J. R. W., Harris, C. R., \& McEwen, F. L. (1980). Behavior of 12 insecticides in soil and aqueous suspensions of soil and sediment. Water Research, 14, 1096-1100.

Sherrard, R. M., Bearr, J. S., Murray-Gulde, C. L., Rodgers, J. H., Jr., \& Shah, Y. T. (2004). Feasibility of constructed wetlands for removing chlorothalonil and chlorpyrifos from aqueous mixtures. Environmental Pollution, 127, 385-394.

US EPA (2004a). 2000-2001 Pesticide sales and usage report. http://www.epa.gov/oppbead $1 /$ pestsales/01 pestsales/ usage2001.html.

US EPA (2004b). http://oaspub.epa.gov/waters/national_rept. control\#TOP IMP.

US EPA (2005). Aquatic life ambient water quality criteria diazinon. Office of Water \& Office of Science and Technology 4304T. EPA-822-R-05-006.

Watanabe, H., \& Grismer, M. E. (2001). Diazinon transport through inter-row vegetative filter strips: Micro-ecosystem modeling. Journal of Hydrology, 247, 183-199.

Wauchope, R. D. (1978). The pesticide content of surface water draining from agricultural fields: A review. Journal of Environmental Quality, 7, 459-472.

Weaver, M. A., Zablotowicz, R. M., \& Locke, M. A. (2004). Laboratory assessment of atrazine and fluometuron degradation in soils from a constructed wetland. Chemosphere, $57,853-862$.

Wolverton, B. C., \& Harrison, D. D. (1973). Aquatic plants for the removal of mevinphos for the aquatic environment. Journal of the Mississippi Academy of Sciences, 19, 84-88. 